\title{
From Small Building Blocks to Complex Molecular Architecture
}

\author{
Eugene R. Zubarev, Jun Xu, Jacob D. Gibson, Arshad Sayyad
}

Department of Chemistry, Rice University, Houston, Texas 77005

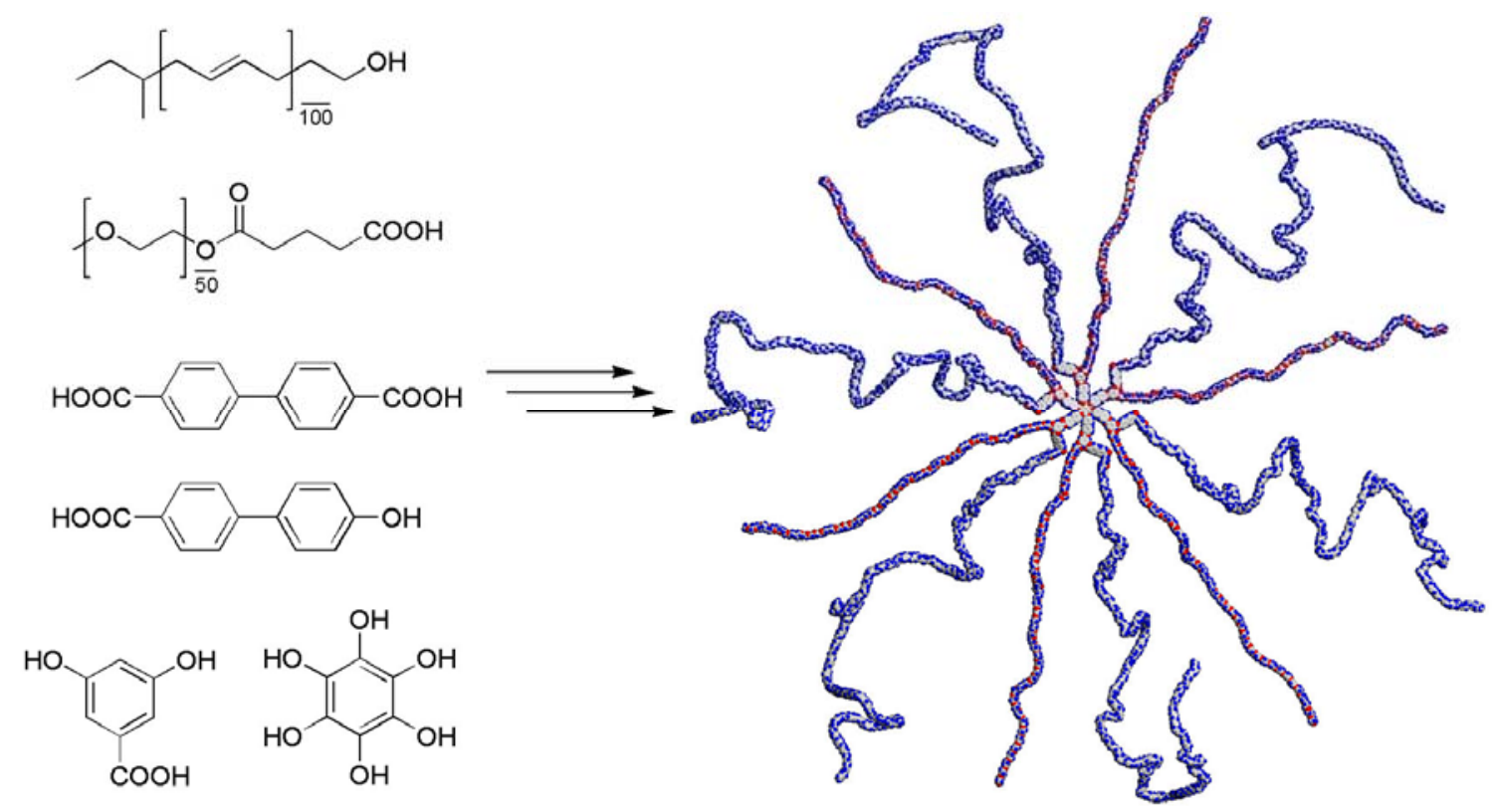

\section{Supporting Information}

General. Unless otherwise stated, all starting materials were obtained from commercial suppliers and used without further purification. The ${ }^{1} \mathrm{H}$ NMR spectra were recorded on solutions in $\mathrm{CD}_{2} \mathrm{Cl}_{2}$ on a Varian Unity $300(300 \mathrm{MHz})$ spectrometer. ${ }^{13} \mathrm{C}$ NMR spectra were recorded at $75 \mathrm{MHz}$ on a Varian Unity 300 spectrometer using the solvent carbon signals as internal references. Matrix-assisted laser desorption/ionization time-of-flight (MALDI-TOF) mass spectra were obtained on a Thermo BioAnalysis Dynamo mass analyser using dithranol as a matrix and lithium trifluoroacetate as a cationizing salt. GPC analysis was conducted on a Waters Breeze 1515 series liquid chromatograph equipped with a dual $\lambda$ absorbance detector (Waters 2487) and three styrogel columns (HR1, HR3, HR4) using linear polystyrene as calibration standards and THF as an eluent. Hydroxyl-terminated polybutadiene containing $90 \%$ of 1,4-addition monomeric units as determined by $\mathrm{NMR}\left(\mathrm{M}_{\mathrm{w}}=5400\right.$, $\mathrm{M}_{\mathrm{w}} / \mathrm{M}_{\mathrm{n}}=1.12$ ) was purchased from Polymer Source, Inc. This polymer was additionally purified by 
flash chromatography on silica gel using a mixture of $\mathrm{THF}$ and $\mathrm{CH}_{2} \mathrm{Cl}_{2}$ (3:97 vol.) as an eluent $\left(\mathrm{R}_{\mathrm{f}}=0.7\right)$. Poly(ethylene oxide) glutarate with the weight-average molecular weight $\mathrm{M}_{\mathrm{w}}=2200$ $\left(\mathrm{M}_{\mathrm{w}} / \mathrm{M}_{\mathrm{n}}=1.15\right)$ was also purchased from Polymer Source, Inc. and was used as received. 4-(N,Ndimethylamino)pyridinium-4- $p$-toluenesulfonate (DPTS) was prepared by mixing saturated THF solutions of DMAP (1 equiv) and p-toluenesulfonic acid monohydrate (1 equiv) at room temperature. The precipitate was filtered, washed several times with THF, and dried under vacuum. The structure of DPTS was confirmed by ${ }^{1} \mathrm{H}$ NMR.

General procedure for esterification coupling reactions. The acid (1 equiv), phehol or hydroxylterminated core ( 1 equiv), DPTS (1.5 equiv), and $\mathrm{CH}_{2} \mathrm{Cl}_{2}$ were combined in a round-bottom flask and stirred at room temperature for $5 \mathrm{~min}$. 1,3-Diisopropyl carbodiimide (DIPC, 5 equiv) was added dropwise after $5 \mathrm{~min}$ and the solution was allowed to stir for 12-16 hours. The coupling reactions were monitored by TLC, GPC, and NMR. Some of the esterification reactions reported here were found to proceed very rapidly at room temperature and nearly complete disappearance of starting materials was typically observed within 1-3 $\mathrm{h}$. The reaction mixture was then diluted by dichloromethane and 2-4 extractions with DI water were used to quench the reaction and to remove DPTS. The crude product was purified by column chromatography on silica gel and/or dialysis against DI water for several days as outlined below.

\section{General procedure for the deprotection reactions using tetrabutyl ammonium fluoride (TBAF).}

Triisopropylsilyl (TIPS) protected acid (1 equiv) was dissolved in THF and cooled to $-78{ }^{\circ} \mathrm{C}$ using dry ice-acetone bath. The solution was allowed to stir for $10 \mathrm{~min}$ and 10 equiv of TBAF (1.0 M solution in THF) was slowly added via syringe upon rigorous stirring. Addition of TBAF immediately resulted in appearance of a characteristic yellow-greenish color which remained unchanged throughout the entire reaction. Acetic acid (11 equiv) was added into reaction mixture after $1-2 \mathrm{~h}$ and the stirring proceeded for 10 min to ensure that all residual TBAF was quenched before the mixture was allowed to warm to room temperature. The mixture was then diluted with $\mathrm{CH}_{2} \mathrm{Cl}_{2}$ and washed several times 
with DI water. The organic layer was collected and concentrated in vacuo. The crude product was purified by column chromatography as outlined in the following text.

Biphenyl-4,4'-dicarboxylic acid 4'-triisopropylsilyl ester. Biphenyl-4,4'-dicarboxylic acid (1 equiv) was dissolved in DMF and 0.3 equiv. of triisopropylsilyl chloride (TIPSCl) was added via syringe. The mixture was stirred for $5 \mathrm{~min}$ and 0.33 equiv. of triethyl amine was added dropwise. The reaction was monitored by TLC and was completed after $2 \mathrm{~h}$. The reaction mixture was diluted with 5 fold volume of dichloromethane/THF mixture (70:30 vol.) and DMF was removed upon several extractions with DI water. The product was purified by flash chromatography on silica gel eluting with THF $/ \mathrm{CH}_{2} \mathrm{Cl}_{2}$ (7:93 vol.) mixture $\left(\mathrm{R}_{\mathrm{f}}=0.55\right)$ to give the product as white solid. Yield $53 \%$. ${ }^{1} \mathrm{H}$ NMR (300 MHz, $\mathrm{CD}_{2} \mathrm{Cl}_{2} / \mathrm{THF}_{-} d_{8}$ (9:1 vol.)): $\delta 1.18$ (d, $18 \mathrm{H}, J=8.3 \mathrm{~Hz}, \mathrm{CH}_{3}$ of TIPS), 1.43 (m, $3 \mathrm{H}, \mathrm{CH}$ of TIPS), 7.90 (dd, $4 \mathrm{H}, J=8.3 \mathrm{~Hz}$, biphenyl protons at positions 2,6,2',6'), 8.19 (d, 2H, ArH, $J=8.4 \mathrm{~Hz}$, biphenyl protons at positions 3 and 5), 8.21 (d, 2H, $J=8.4 \mathrm{~Hz}$, biphenyl protons at positions 3' and 5'). PB-OCO-biphenyl-COOTIPS. Hydroxyl-terminated 1,4-polybutadiene (1 equiv), biphenyl-4,4'dicarboxylic acid 4'-triisopropylsilyl ester (1.3 equiv), and DPTS (1.5 equiv) were dissolved in $\mathrm{CH}_{2} \mathrm{Cl}_{2}$ and the mixture was allowed to stir for 5 min before 5 equiv of DIPC was added dropwise. The reaction was monitored by TLC using $\mathrm{CH}_{2} \mathrm{Cl}_{2}$ as an eluent. Complete disappearance of polybutadiene spot $\left(\mathrm{R}_{\mathrm{f}}=0.3\right)$ occurred after $13 \mathrm{~h}$ and the reaction mixture was evaporated and the product was isolated by column chromatography eluting with a mixture of hexane and dichloromethane (30:70 vol.) to give the product as a colorless liquid $\left(\mathrm{R}_{\mathrm{f}}=0.7\right)$. Yield $85 \% .{ }^{1} \mathrm{H} \mathrm{NMR}\left(300 \mathrm{MHz}, \mathrm{CD}_{2} \mathrm{Cl}_{2}\right): \delta 1.18(\mathrm{~d}, 18 \mathrm{H}$, $J=8.2 \mathrm{~Hz}, \mathrm{CH}_{3}$ of TIPS), 1.5-1.2 (br, $71 \mathrm{H}, \mathrm{CH}_{2}$ of 1,2-addition units and $\mathrm{CH}$ from TIPS), 2.2-1.9 (br, $346 \mathrm{H}$, aliphatic $\mathrm{CH}_{2}$ (both cis- and trans-) of 1,4-addition units), 4.33 (br, 2H, $\mathrm{PB}-\mathrm{CH}_{2}-\mathrm{CH}_{2}-\mathrm{O}-$ ), 5.04.9 (br, $20 \mathrm{H}$, vinyl $-\mathrm{CH}=\mathrm{CH}_{2}$ of 1,2-addition units), 5.5-5.3 (br, $162 \mathrm{H}$, both cis- and trans- $\mathrm{CH}=\mathrm{CH}$ of 1,4-addition units), 5.65-.5.5 (br, $10 \mathrm{H}$, vinyl $-\mathrm{CH}=\mathrm{CH}_{2}$ of 1,2-addition units), 7.73 (d, $4 \mathrm{H}, \mathrm{Ar} H, J=$ 8.2 Hz, biphenyl protons at positions 2,6,2',6'), $8.12(\mathrm{~d}, 2 \mathrm{H}, \mathrm{ArH}, J=8.3 \mathrm{~Hz}$, biphenyl protons at 
positions 3 and 5), $8.16(\mathrm{~d}, 2 \mathrm{H}, \mathrm{Ar} H, J=8.1 \mathrm{~Hz}$, biphenyl protons at positions 3' and 5'). GPC (254 $\mathrm{nm}, \mathrm{THF}), \mathrm{M}_{\mathrm{w}}=8100, \mathrm{PDI}=1.12$.

Compound 2. This compound was prepared from PB-OCO-biphenyl-COOTIPS following the standard TBAF deprotection procedure described above. The crude product was purified by column chromatography on silica gel eluting with $5 \% \mathrm{THF} / \mathrm{CH}_{2} \mathrm{Cl}_{2}$ as an eluent $\left(\mathrm{R}_{\mathrm{f}}=0.55\right)$. Yield $90 \%$. ${ }^{1} \mathrm{H}$ NMR (300 MHz, $\mathrm{CD}_{2} \mathrm{Cl}_{2}$ ): $\delta$ 1.5-1.2 (br, $26 \mathrm{H}, \mathrm{CH}_{2}$ of 1,2-addition units), 2.2-1.9 (br, 360H, aliphatic $\mathrm{CH}_{2}$ (both cis- and trans-) of 1,4-addition units), 4.32 (br, 2H, PB- $\mathrm{CH}_{2}-\mathrm{CH}_{2}-\mathrm{O}-$ ), 5.0-4.9 (br, 20H, vinyl $-\mathrm{CH}=\mathrm{CH}_{2}$ of 1,2-addition units), 5.5-5.3 (br, $168 \mathrm{H}$, both cis- and trans- $\mathrm{CH}=\mathrm{CH}$ of 1,4-addition units), 5.65-.5.5 (br, $10 \mathrm{H}$, vinyl $-\mathrm{CH}=\mathrm{CH}_{2}$ of 1,2-addition units), 7.75 (d, 2H, $\mathrm{ArH}, J=8.2 \mathrm{~Hz}$, biphenyl protons at positions 2 and 6), $7.77(\mathrm{~d}, 2 \mathrm{H}, \operatorname{ArH}, J=8.1 \mathrm{~Hz}$, biphenyl protons at positions 2' and 6'), $8.13(\mathrm{~d}, 2 \mathrm{H}, \operatorname{Ar} H, J=8.2 \mathrm{~Hz}$, biphenyl protons at positions 3 and 5), $8.21(\mathrm{~d}, 2 \mathrm{H}, \operatorname{Ar} H, J=$ 8.3 Hz, biphenyl protons at positions 3' and 5'). GPC (254 nm, THF), $\mathrm{M}_{\mathrm{w}}=7960, \mathrm{PDI}=1.12$.

3,5-Dihydroxy-triisopropylsilyl benzoate. Morpholine (1.3 equiv) was added to a homogeneous solution of 3,5-dihydroxybenzoic acid (1 equiv) in DMF. Triisopropylsilyl chloride (1.1 equiv) was added via syringe upon rigorous stirring. The reaction mixture was allowed to stir for exactly 5 minutes at room temperature, then diluted with $\mathrm{CH}_{2} \mathrm{Cl}_{2}$ and washed several times with DI water. The organic layer was evaporated and the crude product was purified by column chromatography on silica gel $\left(5 \%\right.$ THF in $\left.\mathrm{CH}_{2} \mathrm{Cl}_{2}\right)$ to yield the product as a colorless liquid $\left(\mathrm{R}_{\mathrm{f}}=0.4\right)$. Yield: $70 \%$. ${ }^{1} \mathrm{H}$ NMR (300 MHz, $\mathrm{CD}_{2} \mathrm{Cl}_{2}$ ): $\delta 1.13\left(\mathrm{~d}, 18 \mathrm{H}, J=8.2 \mathrm{~Hz}, \mathrm{CH}_{3}\right.$ of TIPS), 1.41 (m, 3H, CH of TIPS), 6.59 (t, $1 \mathrm{H}$, $\operatorname{Ar}^{\prime} H, J=2.0 \mathrm{~Hz}$, DHBA proton at position 4), $7.16\left(\mathrm{~d}, 2 \mathrm{H}, \operatorname{Ar}{ }^{\prime} \mathrm{H}, J=2.2 \mathrm{~Hz}\right.$, DHBA protons at positions 2 and 6).

Compound 3. Compound 2 (1 equiv), was added to a 10 wt. $\% \mathrm{CH}_{2} \mathrm{Cl}_{2}$ solution of 3,5-dihydroxytriisoprorylsilyl benzoate (10 equiv). DPTS (1.5 equiv) was added to the resulting solution and the mixture was stirred for 5 minutes before DIPC ( 5 equiv) was added via pipette. The reaction proceeded for $12 \mathrm{~h}$, although nearly complete disappearance of the activated polybutadiene-biphenyl 
anhydrite spot on TLC $\left(\mathrm{R}_{\mathrm{f}}=1\right.$ in $\left.\mathrm{CH}_{2} \mathrm{Cl}_{2}\right)$ was observed in $3 \mathrm{~h}$. The mixture was diluted with $\mathrm{CH}_{2} \mathrm{Cl}_{2}$ and washed with water 3 times. The product was purified by flash chromatography eluting with $3 \%$ $\mathrm{THF} / \mathrm{CH}_{2} \mathrm{Cl}_{2}$ mixture $\left(\mathrm{R}_{\mathrm{f}}=0.6\right)$ to give 3 as a colorless liquid. Please note, some fractionation of the polymer product occurs as it passes through silica gel. The high molar mass fractions come out of the column first. In order to decrease the overall polydispersity we intentionally cut off early and late fractions, which slightly reduced the isolated yield. Yield: $75 \%$. ${ }^{1} \mathrm{H}$ NMR $\left(300 \mathrm{MHz}, \mathrm{CD}_{2} \mathrm{Cl}_{2}\right): \delta 1.16$ (d, $18 \mathrm{H}, J=8.2 \mathrm{~Hz}, \mathrm{CH}_{3}$ of TIPS), $1.5-1.3$ (br, $28 \mathrm{H}, \mathrm{CH}_{2}$ of 1,2-addition units and $\mathrm{CH}$ from TIPS), 2.2-1.9 (br, 363H, aliphatic $\mathrm{CH}_{2}$ (both cis- and trans-) of 1,4-addition units), 4.34 (br, $2 \mathrm{H}, \mathrm{PB}-\mathrm{CH}_{2}-$ $\mathrm{CH}_{2}-\mathrm{O}-$ ), 5.0-4.9 (br, $22 \mathrm{H}$, vinyl $-\mathrm{CH}=\mathrm{CH}_{2}$ of 1,2-addition units), 5.5-5.3 (br, $200 \mathrm{H}$, both cis- and trans- $\mathrm{CH}=\mathrm{C} H$ of 1,4-addition units), 5.65-.5.5 (br, $17 \mathrm{H}$, vinyl $-\mathrm{C} H=\mathrm{CH}_{2}$ of 1,2-addition units), 7.01 (t, $1 \mathrm{H}$, Ar' $H$, proton at position 4 in DHBA, $J=1.8 \mathrm{~Hz}$ ), 7.45 (br t, $1 \mathrm{H}$, Ar' $H$, protons at position 2 in DHBA), 7.49 (br t, 1H, Ar' $H$, protons at position 6 in DHBA), 7.77 (d, 2H, ArH, $J=8.2 \mathrm{~Hz}$, biphenyl protons at positions 2 and 6), $7.82(\mathrm{~d}, 2 \mathrm{H}, \mathrm{ArH}, J=8.2 \mathrm{~Hz}$, biphenyl protons at positions 2' and 6'), $8.14(\mathrm{~d}, 2 \mathrm{H}, \operatorname{ArH}, J=8.3 \mathrm{~Hz}$, biphenyl protons at positions 3 and 5), 8.29 (d, 2H, ArH, $J=8.4 \mathrm{~Hz}$, biphenyl protons at positions 3' and 5'). GPC (254 nm, THF), $\mathrm{M}_{\mathrm{w}}=8550, \mathrm{PDI}=1.10$.

TIPS-protected PB-DHBA-PEO. Compound 3 (1.2 equiv), glutaric acid terminated PEO (1.0 equiv), and DPTS (1.5 equiv) were dissolved in dichloromethane. DIPC (5 equiv) was added after 5 min and the reaction was stirred for $12 \mathrm{~h}$. The reaction was monitored by TLC and GPC since the molecular weight of the product is much higher than that of both starting materials. The reaction mixture was washed 3 times with DI water and the product was purified by column chromatography using $11 \%$ $\mathrm{MeOH} / \mathrm{CHCl}_{3}$ mixture as an eluent. The product can also be purified by several precipitations from THF solution upon addition of $30 \%$ (vol.) hexanes. Yield $82 \%$. ${ }^{1} \mathrm{H}$ NMR $\left(300 \mathrm{MHz}, \mathrm{CD}_{2} \mathrm{Cl}_{2}\right): \delta 1.16$ (d, $18 \mathrm{H}, J=8.2 \mathrm{~Hz}, \mathrm{CH}_{3}$ of TIPS), $1.5-1.3$ (br, $38 \mathrm{H}, \mathrm{CH}_{2}$ of 1,2-addition units and $\mathrm{CH}$ from TIPS), 2.2-1.9 (br, 410H, aliphatic $\mathrm{CH}_{2}$ (both cis- and trans-) of 1,4-addition units), 2.25 (m, 2H, PEO-OCO$\left.\mathrm{CH}_{2}-\mathrm{CH}_{2}-\mathrm{CH}_{2}-\mathrm{CO}-\right), 2.52$ (t, $\left.2 \mathrm{H}, J=8.0 \mathrm{~Hz}, \mathrm{PEO}-\mathrm{OCO}-\mathrm{CH}_{2}-\mathrm{CH}_{2}-\mathrm{CH}_{2}-\mathrm{CO}-\right), 2.72$ (t, $2 \mathrm{H}, J=8.0 \mathrm{~Hz}$, 
PEO-OCO- $\mathrm{CH}_{2}-\mathrm{CH}_{2}-\mathrm{CH}_{2}-\mathrm{CO}-$ ), 3.33 (s, 3H, $\mathrm{CH}_{3}$ from PEO), 3.7-3.5 (br, $198 \mathrm{H}, \mathrm{CH}_{2}$ from PEO), 3.82 (t, 2H, PEO-CH $\mathrm{CH}_{2}-\mathrm{CH}_{2}-\mathrm{O}-$ ), 4.26 (t, 2H, $\mathrm{PEO}-\mathrm{CH}_{2}-\mathrm{CH}_{2}-\mathrm{O}-$ ), 4.35 (br, 2H, PB-CH$-\mathrm{CH}_{2}-\mathrm{O}-$ ), 5.1 4.9 (br, $24 \mathrm{H}$, vinyl $-\mathrm{CH}=\mathrm{CH}_{2}$ of 1,2-addition units), 5.5-5.3 (br, $188 \mathrm{H}$, both cis- and trans- $\mathrm{CH}=\mathrm{CH}$ of 1,4-addition units), 5.68-.5.52 (br, $16 \mathrm{H}$, vinyl $-\mathrm{CH}=\mathrm{CH}_{2}$ of 1,2-addition units), 7.33 (t, 1H, Ar' $H, J=$ $1.8 \mathrm{~Hz}$, proton at position 4 in DHBA), 7.72 (br t, 1H, Ar' $H$, proton at position 2 in DHBA), 7.78 (d, $2 \mathrm{H}, \operatorname{Ar} H, J=8.2 \mathrm{~Hz}$, biphenyl protons at positions 2 and 6$), 7.83$ (d, 3H, two protons from biphenyl positions 2' and 6', and one proton from DHBA at position 6), 8.15 (d, 2H, $\mathrm{ArH}, J=8.3 \mathrm{~Hz}$, biphenyl protons at positions 3 and 5), $8.31(\mathrm{~d}, 2 \mathrm{H}, \operatorname{ArH}, J=8.3 \mathrm{~Hz}$, biphenyl protons at positions 3' and 5'). GPC (254 nm, THF), $\mathrm{M}_{\mathrm{w}}=14100, \mathrm{PDI}=1.13$.

Compound 4. This compound was prepared from TIPS-protected PB-DHBA-PEO following the standard procedure for TBAF deprotection described above. The crude product was purified by column chromatography using $11 \% \mathrm{MeOH} / \mathrm{CHCl}_{3}$ mixture as an eluent to give 4 as a tacky solid. Yield $90 \%$. ${ }^{1} \mathrm{H}$ NMR (300 MHz, $\mathrm{CD}_{2} \mathrm{Cl}_{2}$ ): $\delta$ 1.6-1.2 (br, $27 \mathrm{H}, \mathrm{CH}_{2}$ of PB 1,2-addition units), 2.2-1.8 (br, $400 \mathrm{H}$, aliphatic $\mathrm{CH}_{2}$ (both cis- and trans) of 1,4-addition units), 2.26 (m, 2H, PEO-OCO-CH $2^{-}$ $\left.\mathrm{CH}_{2}-\mathrm{CH}_{2}-\mathrm{CO}-\right), 2.53$ (t, $\left.2 \mathrm{H}, J=8.0 \mathrm{~Hz}, \mathrm{PEO}-\mathrm{OCO}-\mathrm{CH}_{2}-\mathrm{CH}_{2}-\mathrm{CH}_{2}-\mathrm{CO}-\right), 2.70$ (t, $2 \mathrm{H}, J=8.0 \mathrm{~Hz}$, PEO-OCO- $\mathrm{CH}_{2}-\mathrm{CH}_{2}-\mathrm{CH}_{2}-\mathrm{CO}-$ ), 3.34 (s, 3H, $\mathrm{CH}_{3}$ from PEO), 3.7-3.5 (br, 228H, $\mathrm{CH}_{2}$ from PEO), 3.84 (t, 2H, PEO-CH $\mathrm{CH}_{2}-\mathrm{CH}_{2}-\mathrm{O}-$ ), 4.25 (t, 2H, PEO- $\mathrm{CH}_{2}-\mathrm{CH}_{2}-\mathrm{O}-$ ), 4.35 (br, 2H, PB-CH$-\mathrm{CH}_{2}-\mathrm{O}-$ ), 5.24.9 (br, $22 \mathrm{H}$, vinyl $-\mathrm{CH}=\mathrm{CH}_{2}$ of 1,2-addition units), 5.5-5.3 (br, $176 \mathrm{H}$, both cis- and trans- $\mathrm{CH}=\mathrm{CH}$ of 1,4-addition units), 5.7-5.5 (br, $15 \mathrm{H}$, vinyl $-\mathrm{CH}=\mathrm{CH}_{2}$ of 1,2-addition units), 7.28 (br s, $1 \mathrm{H}$, Ar' $H$, proton at position 4 in DHBA), 7.75 (br d, Ar' $H$, one proton from DHBA at position 2), 7.78 (d, 2H, $\operatorname{Ar} H, J=8.2 \mathrm{~Hz}$, biphenyl protons at positions 2 and 6), $7.82(\mathrm{~d}, 2 \mathrm{H}, \operatorname{Ar} H, J=8.2 \mathrm{~Hz}$, biphenyl protons at positions 2' and 6'), 7.85 (br d, 1H, Ar' $H$, one proton from DHBA at position 6), 8.15 (d, $2 \mathrm{H}, \operatorname{ArH}, J=8.3 \mathrm{~Hz}$, biphenyl protons at positions 3 and 5), 8.31 (d, 2H, $\operatorname{Ar} H, J=8.3 \mathrm{~Hz}$, biphenyl protons at positions 3' and 5'). GPC (254 nm, THF), $\mathrm{M}_{\mathrm{w}}=13800, \mathrm{PDI}=1.12$. MALDI-TOF: $\mathrm{M}_{\mathrm{w}}=7363$, $[\mathrm{M}+\mathrm{Li}]^{+}$. 
Hexahydroxybenzene. Stannous chloride dihydrate $(10 \mathrm{~g}, 0.044 \mathrm{~mol})$ was added to a boiling solution of tetrahydroxyquinone $(1 \mathrm{~g}, 0.0058 \mathrm{~mol})$ in hydrochloric acid $(20 \mathrm{~mL}$ of $2.4 \mathrm{~N}$ aqueous solution). After $30 \mathrm{~min}$, an additional amount of $\mathrm{HCl}(25 \mathrm{~mL}$ of $12 \mathrm{~N}$ solution) was added and the mixture was boiled for another $30 \mathrm{~min}$. The reaction mixture was then slowly cooled to room temperature and placed into refrigerator at $-10{ }^{\circ} \mathrm{C}$. The precipitate was filtered and the hexahydroxybenzene was collected on a Buchner funnel. The crude product was redissolved in hot hydrochloric acid (45 $\mathrm{mL}$ of 2.4 $\mathrm{N}$ solution) containing stannous chloride dihydrate $(0.3 \mathrm{~g})$ and decolorizing carbon $(0.1 \mathrm{~g})$. The solution was filtered while hot, and the carbon was rinsed with boiling water. The solution was cooled in a refrigerator at $-10{ }^{\circ} \mathrm{C}$. The precipitate was collected and dried in vacuo to give the hexahydroxybenzene as a white crystalline solid. ${ }^{13} \mathrm{C}$ NMR (75 MHz, DMSO- $\left.d_{6}\right): \delta 128.01$.

DTS-protected hexabiphenyl core. 4'-dimethylthexylsilyloxy-biphenyl-4-carboxylic acid ( 8 equiv) and DPTS (8 equiv) were added to a suspension of hexahydroxybenzene ( 1 equiv) in dichloromethane. DIPC (15 equiv) was added at room temperature and the reaction mixture was allowed to stir for 5 minutes. Small amount of DMF was then added to increase the solubility of hexahydroxybenzene and to accelerate the coupling reaction. The reaction was monitored by TLC and GPC and was found to be complete within 2 hours. The mixture was diluted with $\mathrm{CH}_{2} \mathrm{Cl}_{2}$ and washed with water 3 times. The organic layers were collected, dried and the crude product was purified by flash chromatography eluting with pure dichloromethane to first eliminate excess of the activated biphenyl acid (anhydrite which forms upon addition of DIPC, $\mathrm{R}_{\mathrm{f}}=0.9$ in $\mathrm{CH}_{2} \mathrm{Cl}_{2}$ ) and then gradually increasing polarity of the eluent to $1 \% \mathrm{THF} / \mathrm{CH}_{2} \mathrm{Cl}_{2}$ to give pure product as a white solid. Yield: 70 \%. ${ }^{1} \mathrm{H}$ NMR $\left(400 \mathrm{MHz}, \mathrm{CD}_{2} \mathrm{Cl}_{2}\right): \delta 0.28(\mathrm{~s}, 6 \mathrm{H}), 0.98($ br s, $12 \mathrm{H}), 1.78(\mathrm{~m}, 1 \mathrm{H}), 6.85(\mathrm{~d}, 2 \mathrm{H}, J=8.24$ $\mathrm{Hz}$ ), 7.35 (br s, 4H), 7.97 (br s, 2H). ${ }^{13} \mathrm{C} \mathrm{NMR}\left(100 \mathrm{MHz}, \mathrm{CD}_{2} \mathrm{Cl}_{2}\right): \delta-1.96,18.99,20.53,25.64$, $34.72,121.19,126.93,128.70,131.60,132.36,135.43,146.46,156.93,162.25$. 
Hexabiphenyl core (5). 20 wt. \% solution of DTS-protected hexabiphenyl compound in THF was placed into a plastic container and excess ( $\sim 50$ equiv) hydrofluoric acid (49\% aq. solution of HF) was added via syringe upon rigorous stirring. The reaction was allowed to stir for $24 \mathrm{~h}$ at room temperature and then for $2 \mathrm{~h}$ at $50{ }^{\circ} \mathrm{C}$. The mixture was cooled to room temperature, diluted with dichloromethane and quenched with aqueous saturated solution of sodium bicarbonate while in the plastic bottle. The organic layer was additionally washed 3 times with water and the product was precipitated into hexane. The precipitate was filtered and washed several time with pure dichloromethane to give compound 4 as a white solid $\left(\mathrm{R}_{\mathrm{f}}=0.45\right.$ in $\left.50 \% \mathrm{THF} / \mathrm{CH}_{2} \mathrm{Cl}_{2}\right)$. Yield: $98 \%$. MALDI-TOF MS $m / z$ 1358.45 [M+Li] ${ }^{+} .{ }^{1} \mathrm{H}$ NMR (300 MHz, acetone- $\left.d_{6}\right): \delta 6.86(\mathrm{~d}, 2 \mathrm{H}, J=8.67 \mathrm{~Hz})$, $7.21(\mathrm{~d}, 2 \mathrm{H}, J=6.34 \mathrm{~Hz}), 7.36(\mathrm{~d}, 2 \mathrm{H}, J=8.54 \mathrm{~Hz}), 7.90(\mathrm{~d}, 2 \mathrm{H}, J=8.3 \mathrm{~Hz}), 8.73(\mathrm{~s}, 1 \mathrm{H}, \mathrm{OH}) .{ }^{13} \mathrm{C}$ NMR $\left(100 \mathrm{MHz}, \mathrm{DMSO}-d_{6}\right.$ and acetone- $\left.d_{6}\right): \delta 116.20,125.42,127.95,128.01,128.27,130.91,134.37$, $145.86,158.81,161.05$.

Compound 1. PB-PEO diblock 4 (6.3 equiv) and DPTS (8 equiv) were added to a suspension of hexabipenyl core 5 in dichloromethane. After $5 \mathrm{~min}$, DIPC (12 equiv) was added dropwise and the reaction mixture was allowed to stir at room temperature for $3 \mathrm{~h}$. The completion of the coupling reaction was observed by TLC and GPC as the new sharp peak of a high molar mass product $\left(\mathrm{M}_{\mathrm{w}}=49857\right)$ appeared in the GPC trace, whereas the peak of the starting material $\left(\mathrm{M}_{\mathrm{w}}=13814\right)$ gradually disappeared. The new product had a slightly higher $\mathrm{R}_{\mathrm{f}}$ in comparison with the starting material 4 (0.65 versus 0.55 in $11 \% \mathrm{MeOH} / \mathrm{CHCl}_{3}$, respectively). The reaction mixture was diluted with dichloromethane and washed 3 times with water. The crude product was purified by dialysis of DMF solution against DI water for 4 days (molecular weight cut-off of the dialysis membrane was 50,000). The water was evaporated by blowing air through the flask for $12 \mathrm{~h}$. The polymer was then dried on vacuum line at $50{ }^{\circ} \mathrm{C}$ for $24 \mathrm{~h}$. Yield: $85 \%$. GPC (254 nm, THF) PDI=1.14, $\mathrm{M}_{\mathrm{w}}=49,800 .{ }^{1} \mathrm{H}$ NMR (300 MHz, $\mathrm{CD}_{2} \mathrm{Cl}_{2}$ ): $\delta$ 1.5-1.2 (br, $28 \mathrm{H}, \mathrm{CH}_{2}$ of PB 1,2-addition units), 2.2-1.8 (br, 425H, aliphatic $\mathrm{CH}_{2}$ (both cis- and trans) of 1,4-addition units), 2.26 (m, 2H, PEO-OCO-CH$-\mathrm{CH}_{2}-\mathrm{CH}_{2}-\mathrm{CO}-$ 
), 2.53 (br t, $2 \mathrm{H}, \mathrm{PEO}-\mathrm{OCO}-\mathrm{CH}_{2}-\mathrm{CH}_{2}-\mathrm{CH}_{2}-\mathrm{CO}-$ ), 2.70 (br, $2 \mathrm{H}, J=8.0 \mathrm{~Hz}, \mathrm{PEO}-\mathrm{OCO}-\mathrm{CH}_{2}-\mathrm{CH}_{2}-\mathrm{CH}_{2}-$ CO-), 3.35 (s, $3 \mathrm{H}, \mathrm{CH}_{3}$ from PEO), 3.7-3.5 (br, $198 \mathrm{H}, \mathrm{CH}_{2}$ from $\mathrm{PEO}$ ), 3.84 (br, 2H, $\mathrm{PEO}-\mathrm{CH}_{2}-\mathrm{CH}_{2}-$ O-), 4.32 (t, 2H, PEO-CH $\mathrm{CH}_{2}-\mathrm{CH}_{2}-\mathrm{O}-$ ), 4.52 (br, 2H, PB- $\mathrm{CH}_{2}-\mathrm{CH}_{2}-\mathrm{O}-$ ), 5.1-4.9 (br, $19 \mathrm{H}$, vinyl - $\mathrm{CH}=\mathrm{CH}_{2}$ of 1,2-addition units), 5.5-5.3 (br, $178 \mathrm{H}$, both cis- and trans- $\mathrm{CH}=\mathrm{CH}$ of 1,4-addition units), 5.7-5.5 (br, $16 \mathrm{H}$, vinyl - $\mathrm{CH}=\mathrm{CH}_{2}$ of 1,2-addition units), 7.38 (br t, $1 \mathrm{H}, \mathrm{Ar}^{\prime} H$, proton at position 4 in DHBA), 7.77 (d, $5 \mathrm{H}, \operatorname{Ar} H$, two biphenyl protons at positions 2 and 6 , two core biphenyl protons at positions 2 and 6, and one proton at position 2), $7.83(\mathrm{~d}, 4 \mathrm{H}, \mathrm{ArH}$, two biphenyl protons at positions 2' and 6', and two core biphenyl protons at positions 2' and 6'), 7.89 (br, 1H, Ar' $H$, proton at position 6 in DHBA), $7.96(\mathrm{~d}, 2 \mathrm{H}, \operatorname{Ar} H$, two protons from core biphenyl at positions 3' and 5'), $8.15(\mathrm{~d}, 2 \mathrm{H}, \operatorname{Ar} H, J=8.3$ $\mathrm{Hz}$, biphenyl protons at positions 3 and 5), 8.33 (br, 4H, $\mathrm{ArH}$, two biphenyl protons at positions 3 ' and 5', and and two protons from core biphenyls at positions 3 and 5). 

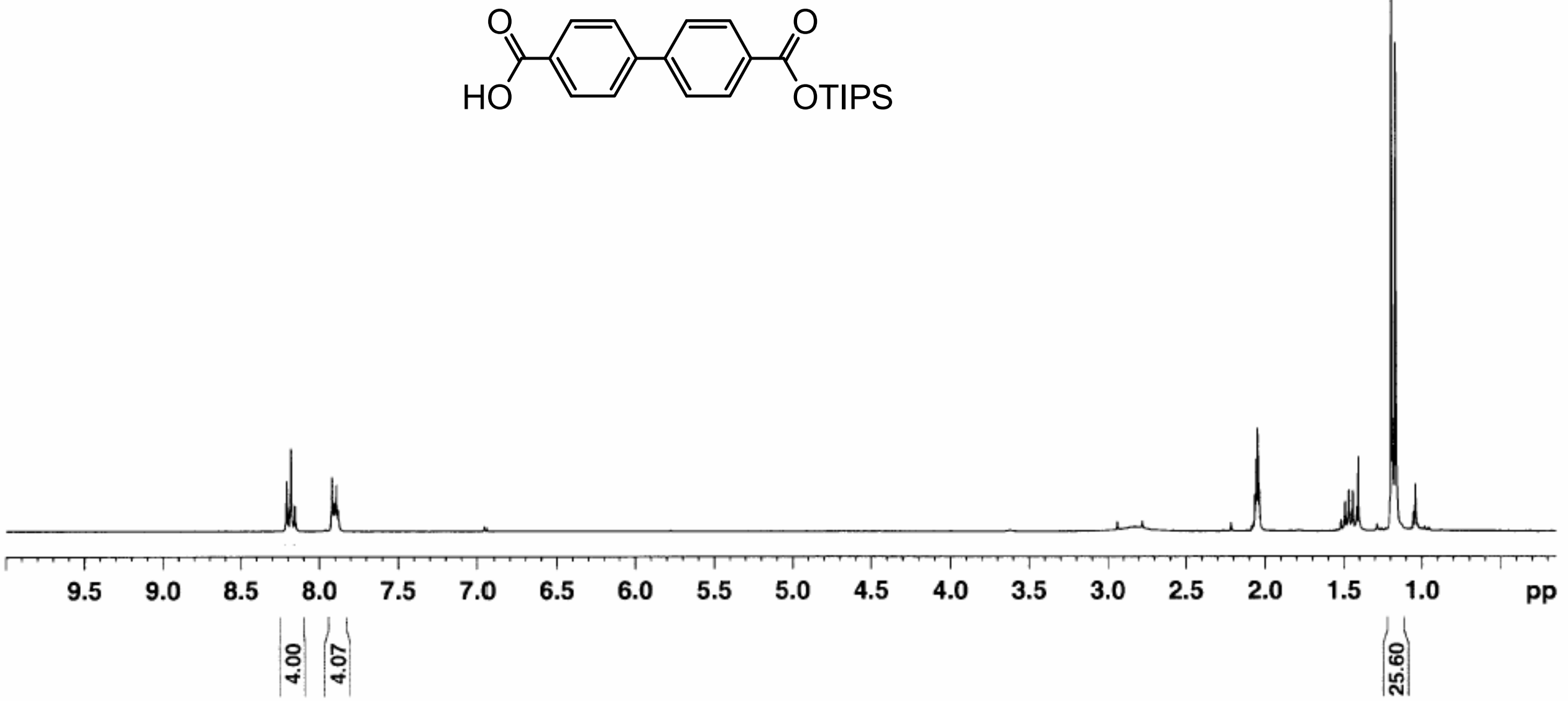
m山n

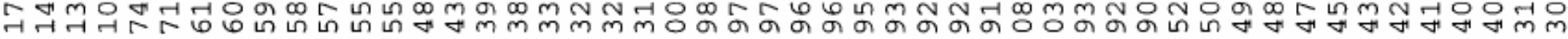

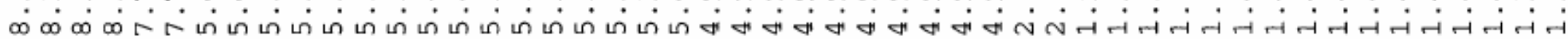

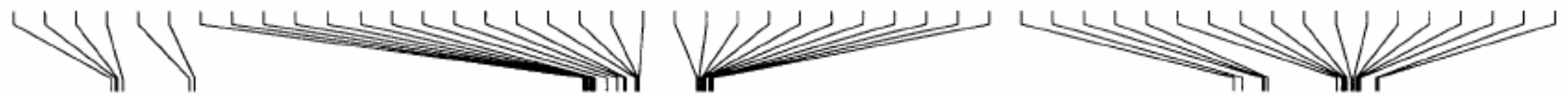

Current Data Parameters

NAME jx30904c.fic

EXPNO

PROCNO

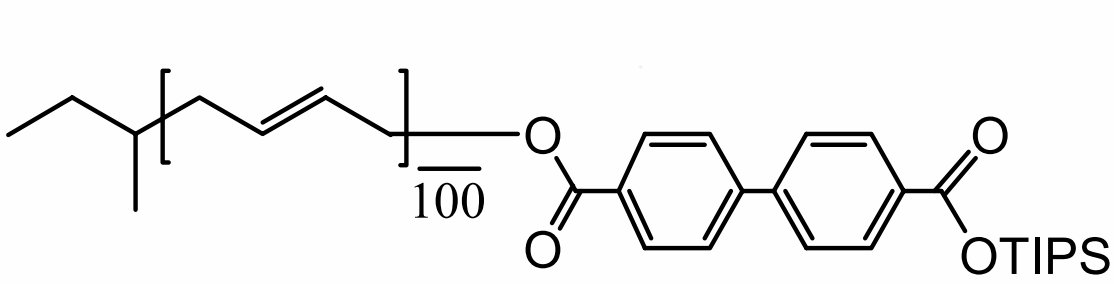

junxu_030904C_PB_BP_COOTIPS

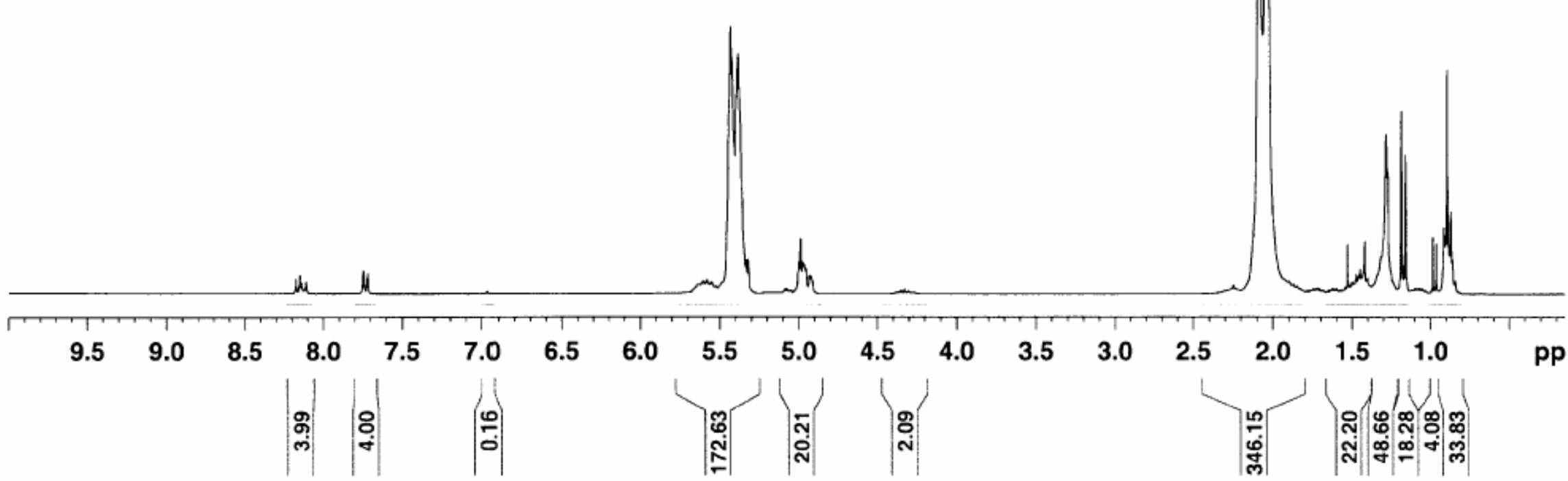


m

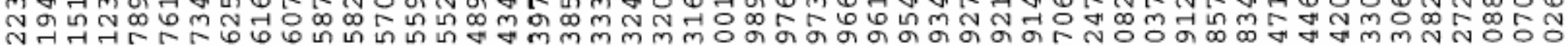
舟 W1।

junxu030904d_PB_BP_COOH
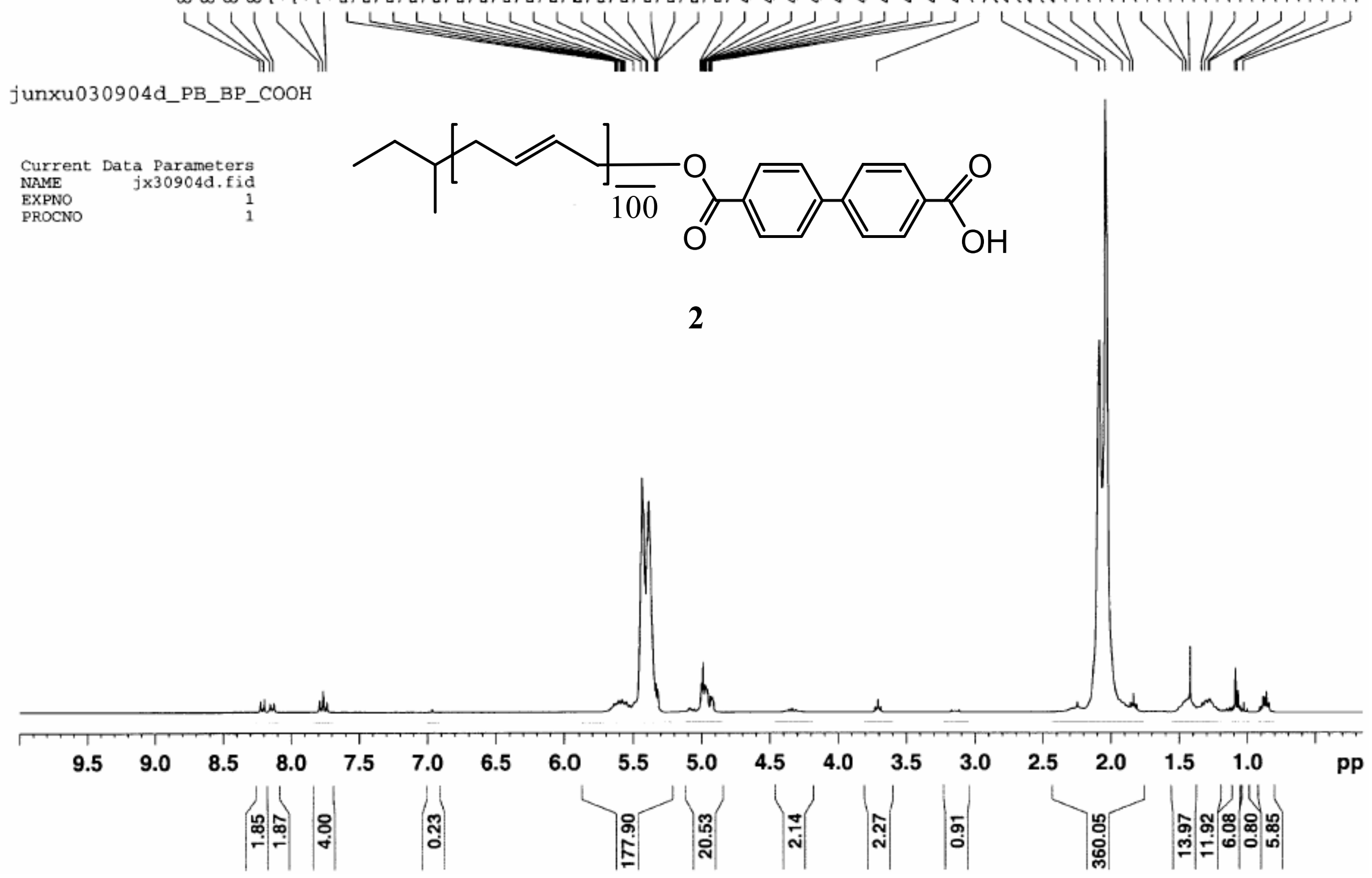


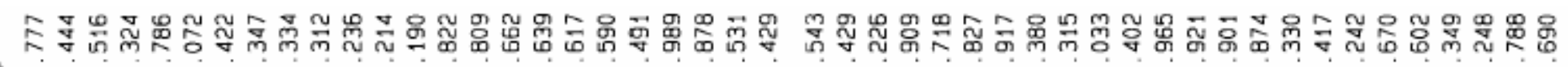

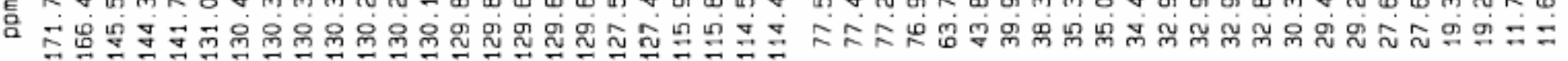

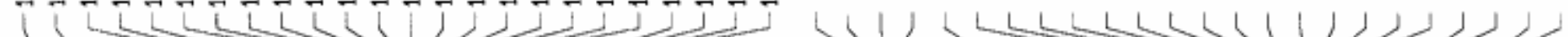

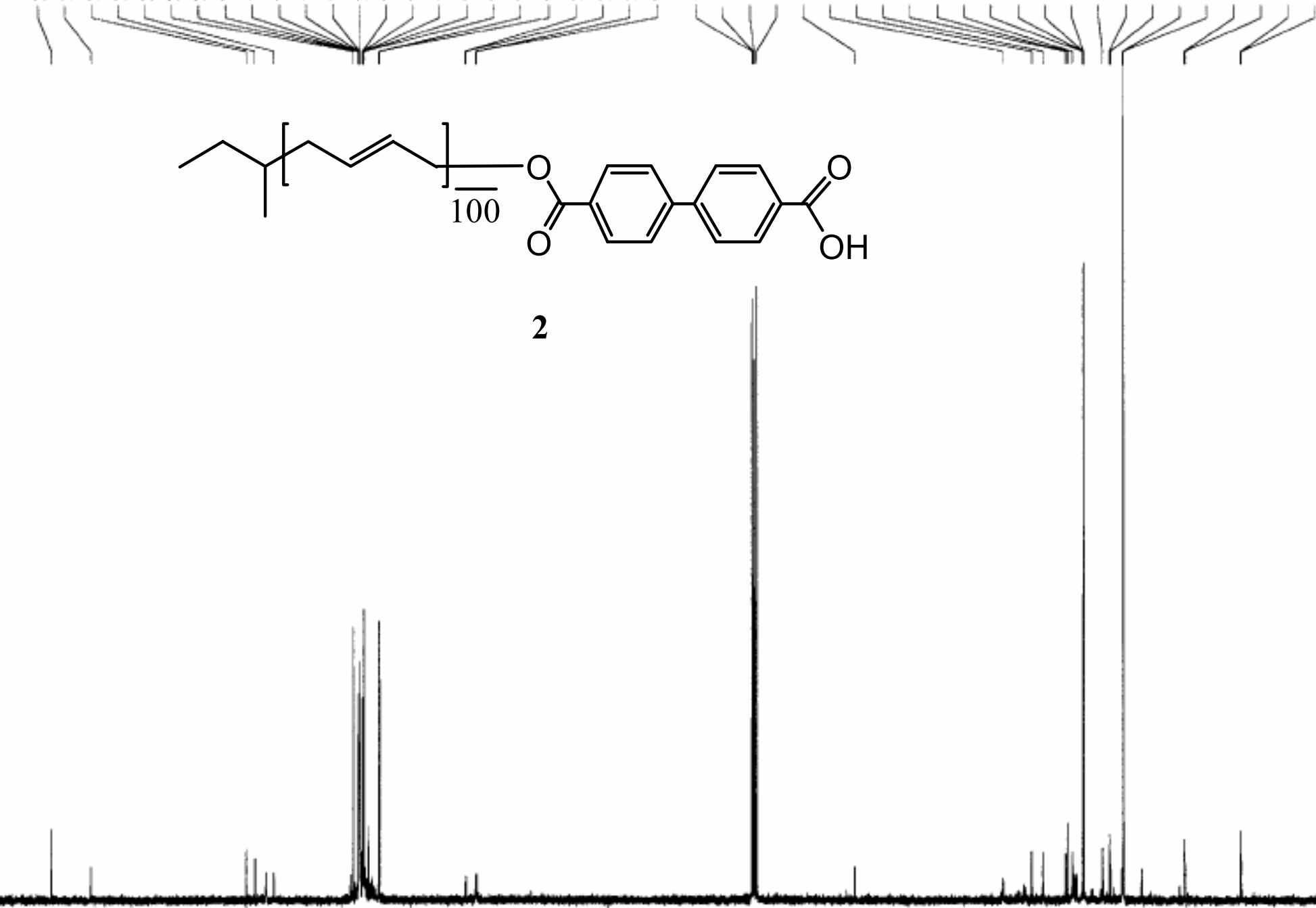




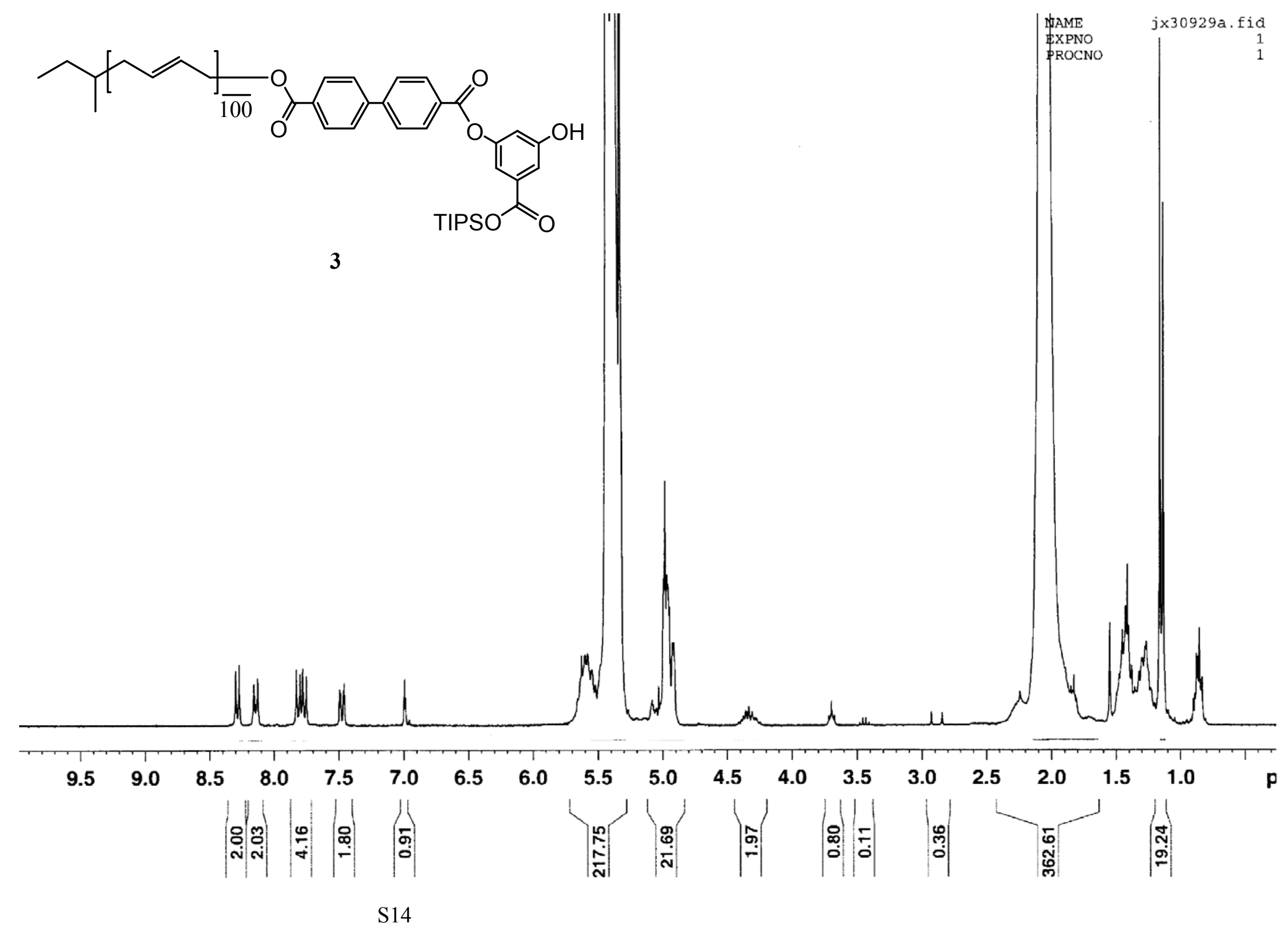




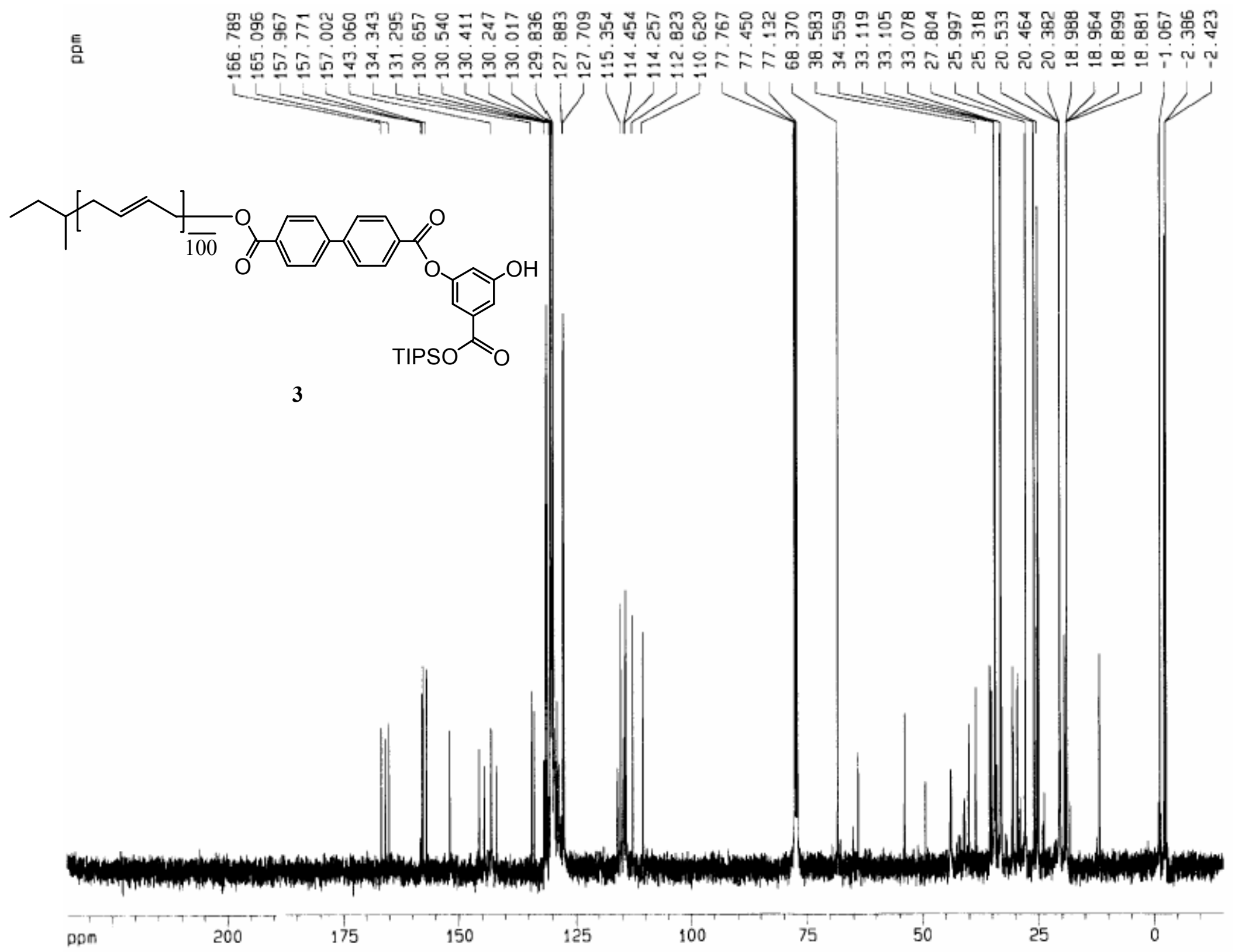




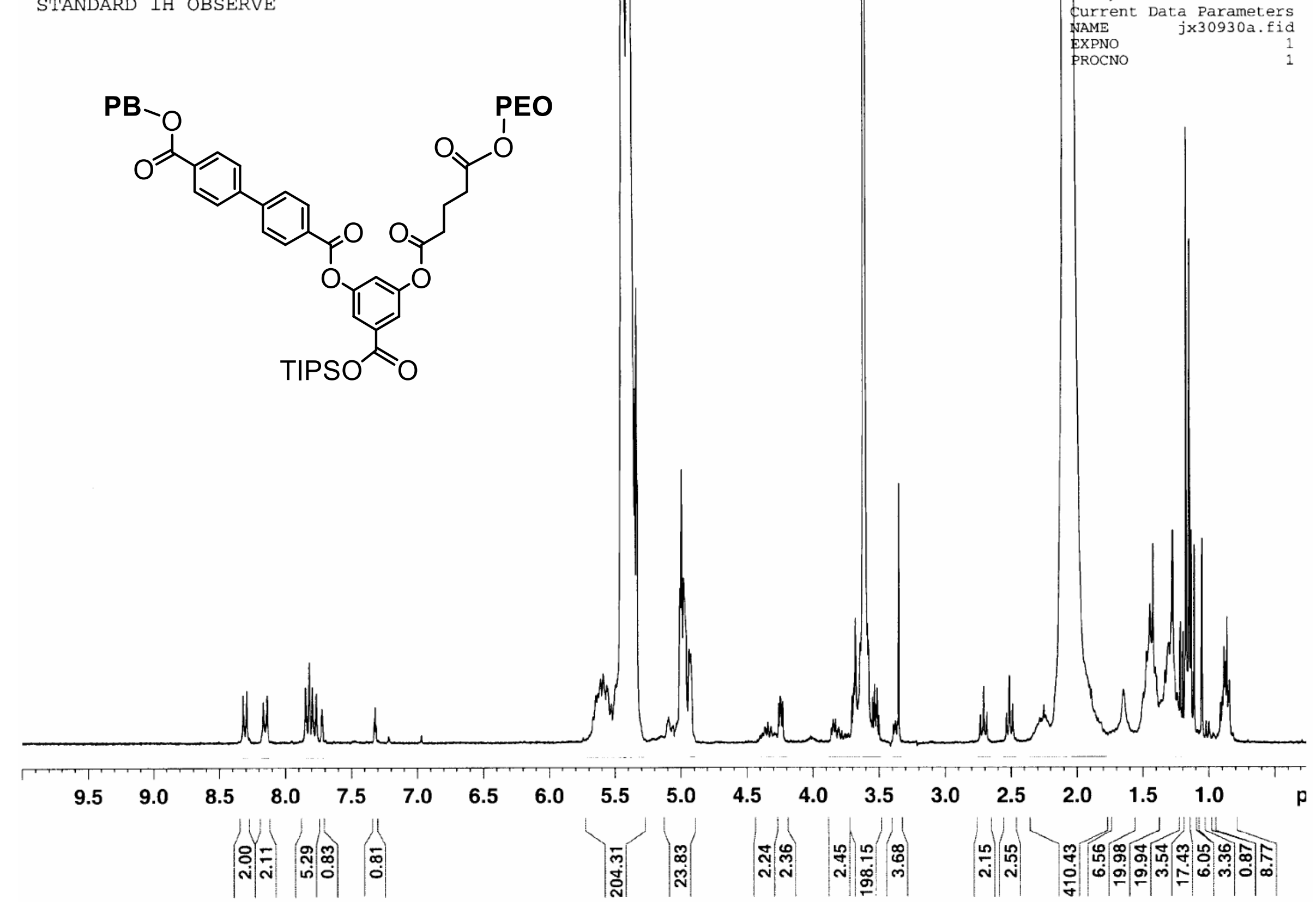




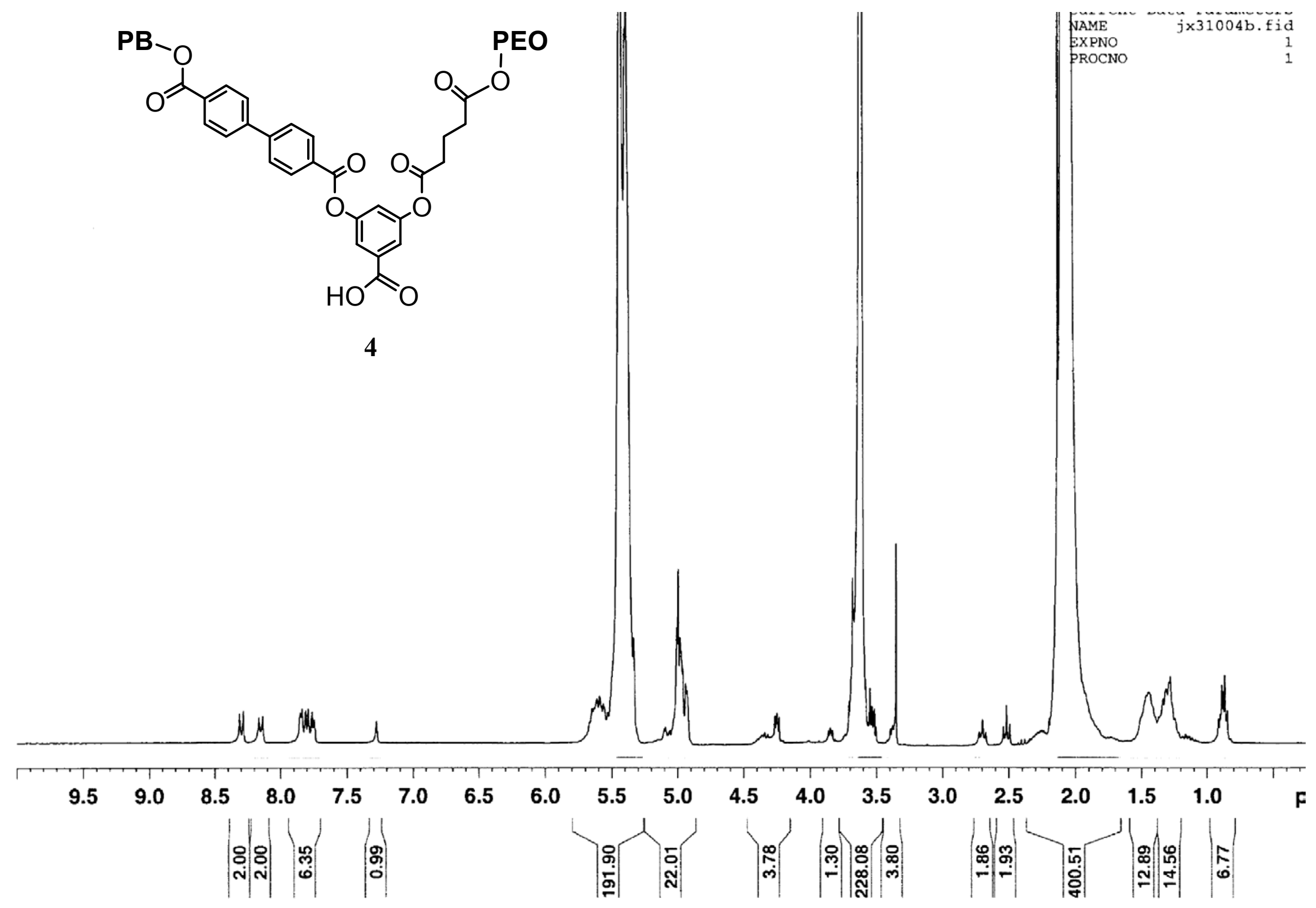




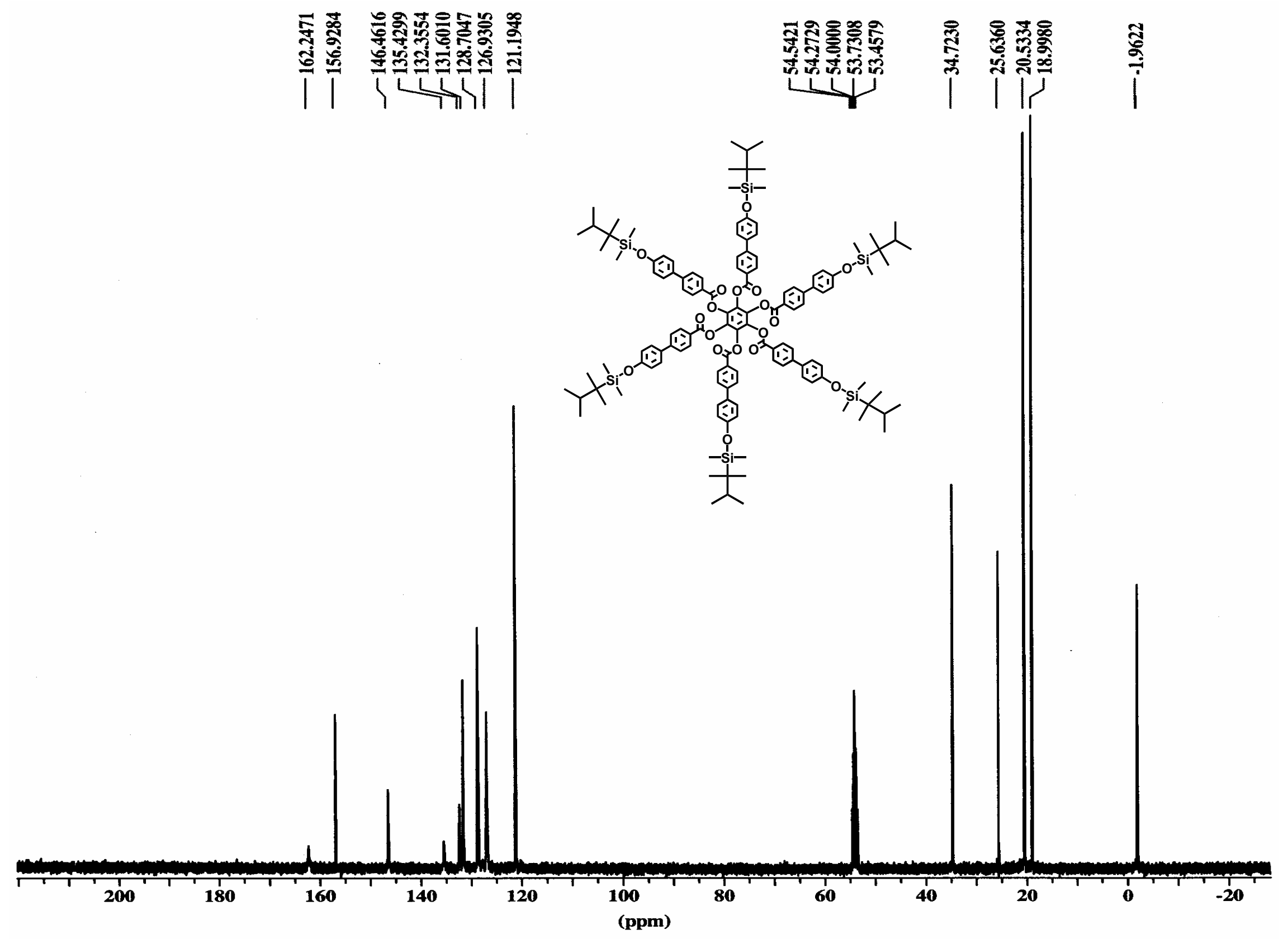




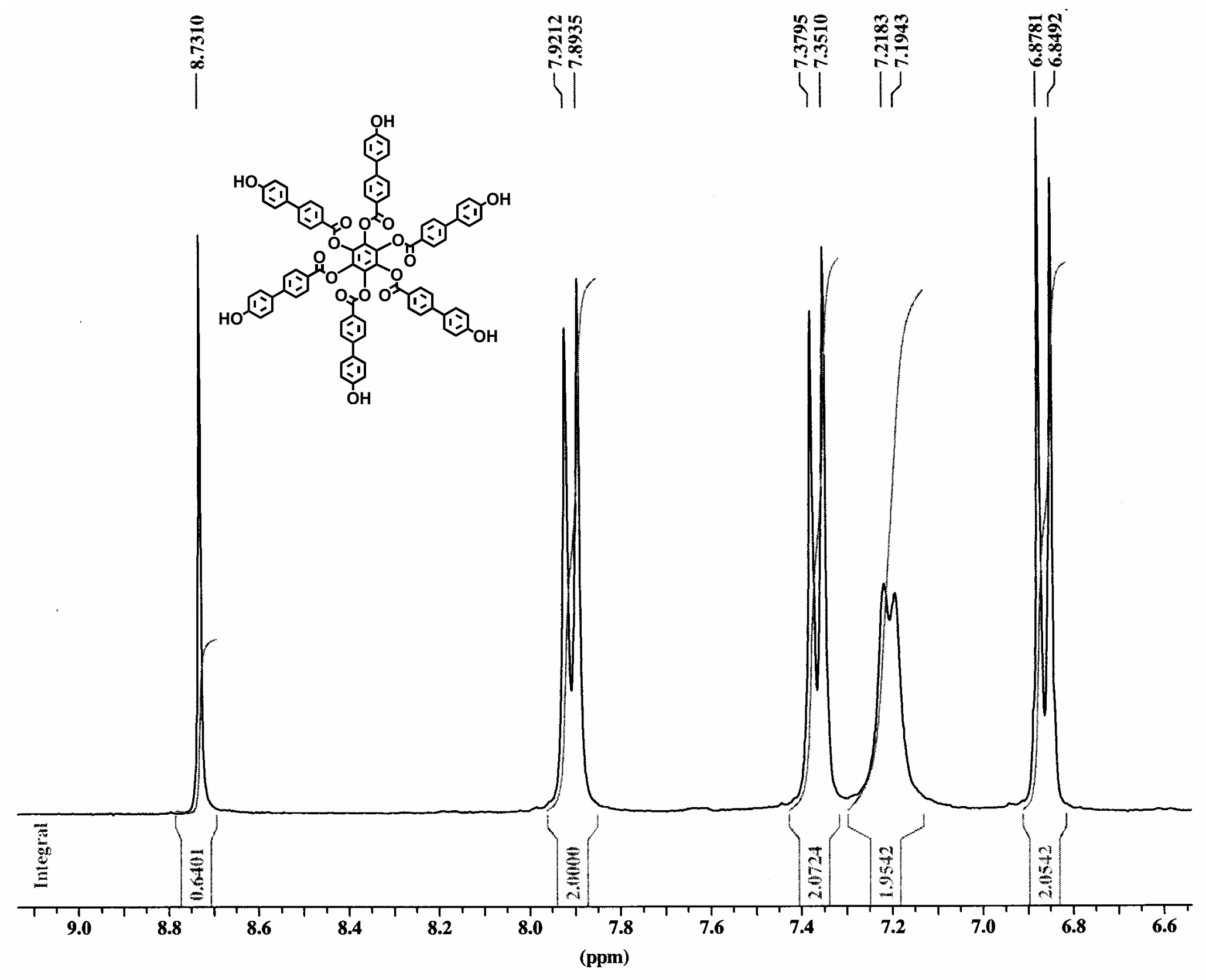

S19 


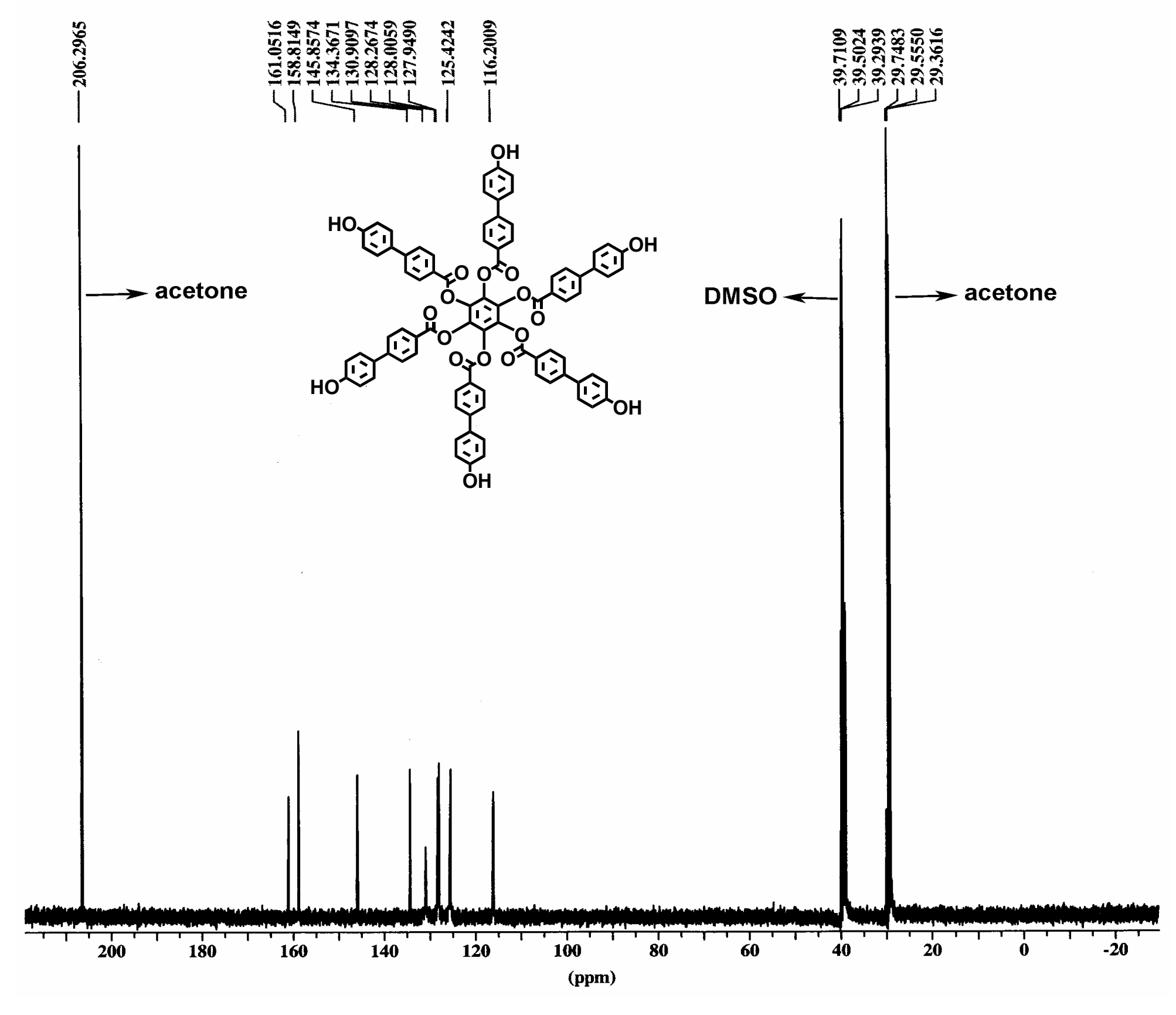




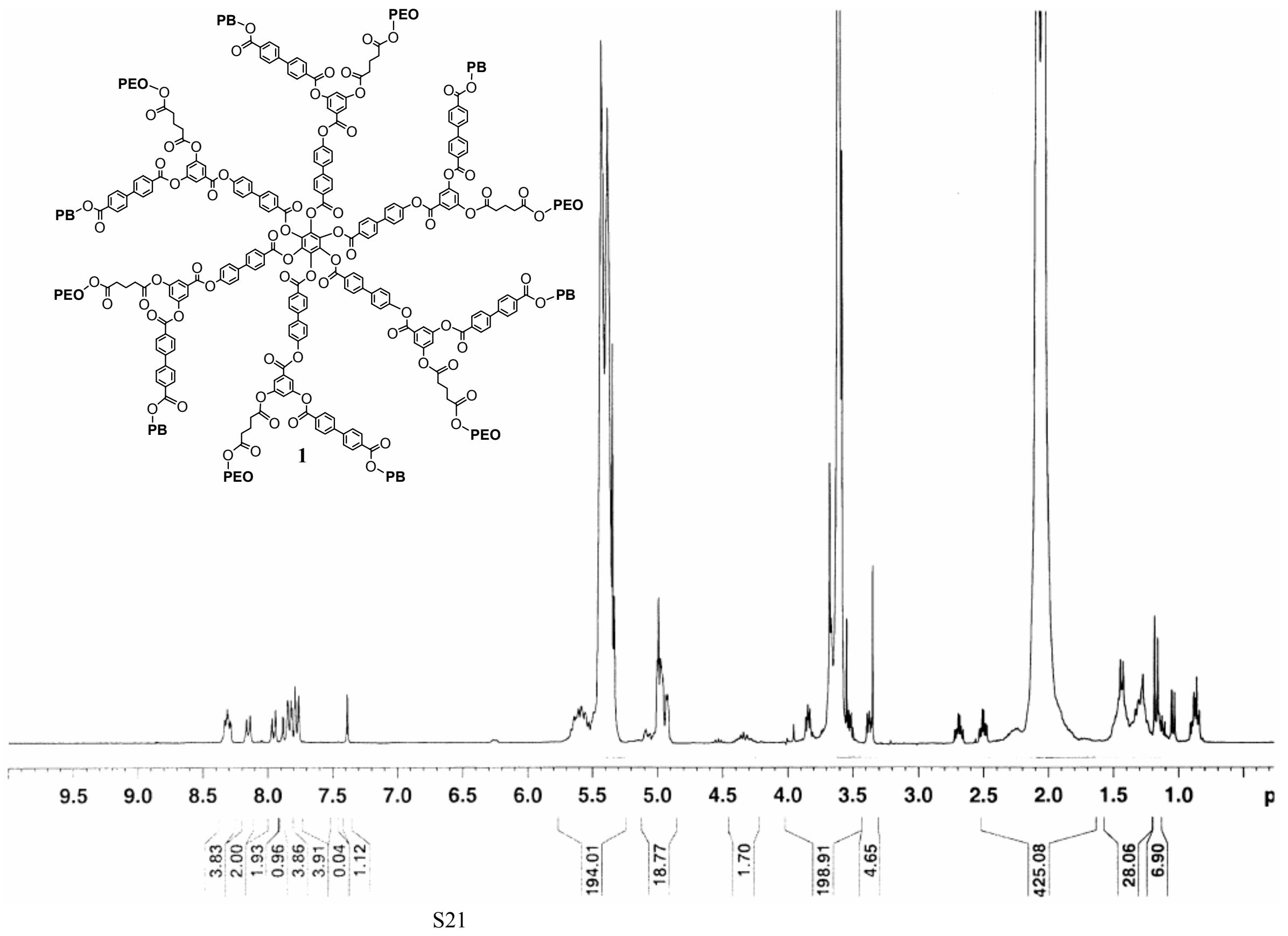

